\title{
PENGEMBANGAN MODEL PEMBELAJARAN SINEKTIK DI MADRASAH IBTIDAIYAH
}

\author{
Rofiatul Hosna
}

Lembaga Penjaminan Mutu IKAHA Tebuireng Jombang

Email: rofiatulhosna@gmail.com

\begin{abstract}
ABSTRAK
Tujuan penelitian ini menghasilkan produk model pembelajaran Sinektk dalam rangka mengembangkan kemampuan berpikir kreatif siswa pada pembelajaran Ilmu Sosial di Madrasah Ibtidaiyah. Penelitian ini dilakukan dengan menggunakan pendekatan penelitian dan pengembangan. Uji validasi dilakukan pada lima madrasah dengan kualifikasi yang dianggap baik, sedang dan kurang. Penelitian ini dikembangkan dengan cara eksperimen dan membandingkan antara model pembelajaran Sinektik (KE) dengan pembelajaran konvensional (KK). Hasil uji validasi menunjukkan bahwa kemampuan siswa untuk berpikir kreatif ternyata berbeda antara hasil test kelompok eksperimen $(\alpha \leq .0001)$ dengan kelompok kontrol $(\alpha \leq$.0001). Hasil penelitian ini menyimpulkan bahwa: 1) Model pembelajaran sinektik adalah model pembelajaran yang diajukan oleh Gordon Synectic. Pengembangan dan modifikasi yang dilakukan berdasarkan kondisi dan kemampuan siswa dalam lingkungan lokal Ibtidaiyah Madrasah; 2) Implementasi model pembelajaran Sinektik dapat meningkatkan kondisi belajar pada Mata Pelajaran Ilmu Sosial di Madrasah Ibtidaiyah; 3) Model pembelajaran sinektik efektif untuk meningkatkan kemampuan berpikir kreatif dan hasil belajar siswa pada Mata Pelajaran Ilmu Pengetahuan Sosial, serta meningkatkan kinerja guru.
\end{abstract}

Kata Kunci: Sinektik, Ilmu Pengetahuan Sosial, Madrasah Ibtidaiyah.

\section{ABSTRACT}

The purpose of this study is to produce synectic learning model in order to develop students' creative thinking skills in teaching Social Studies in the Madrasab Ibtidaiyah. This research was conducted using research and development approach. Validation testing was performed in five madrasas of which the qualification are considered good, moderate and less. This study was developed by doing experiments and comparing between Synectic Learning Model (KE) and Conventional Model $K K)$. Validation test results indicated that students' ability to think creatively was different between the test results of the experimental group $(a \leq .0001)$ and the control group $(a \leq .0001)$. The result of this study concluded that: 1) Synectic Learning Model is the learning model proposed by Gordonsynectic. The development and modifications were made based on the condition and capability of students in the l Environtment of Elementary Madrasab; 2) The Implementation of synectic learning model can improve learning conditions on the subjects of Social Studies in Elementary Madrasah; 3) synectic learning model is effective to enhance creative thinking skills and student learning outcomes on the subjects of Social Sciences, as well as improving teacher performance.

Keywords: Synectic, Social Sciences, Madrasah Ibtidaiyah. 


\section{PENDAHULUAN}

Penyelenggaraan pendidikan di Indonesia cenderung hanya fokus pada pendidikan formal/sekolah. Ruang lingkup pendidikan pun menjadi tertuju pada praktik mengajar dan hanya bersumber pada buku teks. Untuk mengubah paradigma tersebut, perlu dilakukan upaya berkelanjutan dan terintegrasi, khususnya dalam proses pembelajaran serta implementasi kurikulum di kelas. Bagaimanapun juga, dalam konteks pendidikan formal, semakin bermutu suatu proses pembelajaran dan implementasi kurikulum di kelas maka semakin meningkat kualitas hasil belajar siswa. Kualitas hasil belajar siswa tidak hanya tergambarkan pada kemampuan berpikir siswa yang konvergen, tetapi juga melingkupi kemampuan berpikir kreatif.

Dalam kurikulum Ilmu Pengetahuan Sosial (IPS) di Madrasah Ibtidaiyah dinyatakan bahwa mata pelajaran IPS di Madrasah Ibtidaiyah bertujuan memberikan sejumlah kemampuan kepada siswa, yaitu: 1) mengenal konsepkonsep yang berkaitan dengan kehidupan masyarakat dan lingkungannya; 2) berpikir logis dan kritis, rasa ingin tahu, inkuiri, memecahkan masalah dan keterampilan dalam kehidupan sosial; 3) memiliki komitmen dan kesadaran terhadap nilai-nilai sosial dan kemanusiaan; dan 4) memiliki kemampuan berkomunikasi, bekerjasama dan berkompetisi dalam masyarakat yang majemuk, baik di tingkat lokal, nasional maupun global (Depdiknas, 2003).

Hasan (1993:92) mengatakan bahwa pendidikan IPS bertujuan mengembangkan kemampuan berpikir, sikap dan nilai peserta didik sebagai individu maupun sebagai makhluk sosial dan budaya. Numan Soemantri (2001: 44) kemudian menegaskan bahwa kemampuan berpikir yang hendak dikembangkan dalam mata pelajaran IPS bukan saja kemampuan berpikir analitis dan kritis, akan tetapi juga berpikir kreatif. Berarti, peningkatan kemampuan berpikir kreatif merupakan salah satu tujuan pembelajaran IPS di sekolah/madrasah.

Pembelajaran IPS di Madrasah Ibtidaiyah sebenarnya dapat memberikan berbagai informasi keberadaan lingkungan di mana siswa tersebut tinggal. Manakala seseorang tidak mengenal, memahami dan mengetahui lingkungannya, maka ia kesulitan untuk menjadi warga masyarakat yang baik. Oleh karena itu, sejak dini siswa harus dipersiapkan untuk mengetahui dan memiliki informasi yang cukup tentang lingkungannya. Fungsi pembelajaran IPS di Madrasah Ibtidaiyah (MI) tersebut tidak mudah untuk diwujudkan. Dalam pelaksanaannya, proses pembelajaran IPS yang berlangsung di MI masih mengalami berbagai persoalan, baik dilihat dari segi guru maupun siswa. Dari segi guru, proses pembelajaran masih monoton dan terlalu berpusat pada guru. Banyak guru kurang mampu mengembangkan materi yang diajarkan, sangat terikat pada kurikulum, terlalu bergantung pada buku paket dan materi pembelajaran terlalu padat (mencakup materi geografi, ekonomi dan sejarah). Sementara, waktu yang dialokasikan sangat terbatas, berbenturan dengan pemberlakuan sistem guru kelas, orientasi penyajian pembelajaran sangat menekankan pada kemampuan 
intelektual, media pembelajaran yang tersedia sangat kurang bahkan tidak mendukung, kurang berkembangnya strategi guru dalam mengajukan pertanyaan, dan sistem evaluasi yang terlalu terpusat pada rayonisasi. Dari segi siswa, materi dan tujuan pembelajaran IPS yang terlalu abstrak, seperti berpikir dan bersikap kritis, cenderung sulit dipahami oleh siswa. Keberadaan mata pelajaran IPS kurang diapresiasi secara baik oleh siswa. Para siswa menganggap bahwa belajar IPS identik dengan menghafal. IPS merupakan bidang studi yang menjemukan dan kurang menantang. Siswa kurang memiliki kemampuan dalam memecahkan masalah sosial, semangat atau motivasi belajarnya rendah, suasana pembelajaran kurang hidup dan menjenuhkan serta kesungguhan siswa dalam proses pembelajaran IPS sangat rendah. Semua ini menyebabkan rendahnya kualitas pembelajaran IPS pada tingkat Madrasah Ibtidaiyah yang mulai diberikan di kelas 3.

Menurut Syafruddin (2001) selama ini, memang model pembelajaran IPS yang diimplementasikan oleh guru masih terlalu konvensional sehingga siswa sulit memperoleh pelayanan pembelajaran yang optimal. Pembelajaran konvensional kurang mengakomodasi variasi dan perbedaan kemampuan serta kreativitas siswa sehingga sulit mendeteksi tercapainya tujuan-tujuan spesifik pembelajaran terutama bagi siswa yang berkemampuan rendah. Model pembelajaran IPS saat ini juga lebih menekankan pada aspek kebutuhan formal dibanding kebutuhan ril siswa sehingga proses pembelajaran terkesan sebagai kegiatan administratif dan belum mengembangkan potensi berpikir siswa secara optimal. Oleh karena itu, untuk mengatasi persoalan tersebut perlu dikaji modelmodel pembelajaran yang dapat digunakan untuk mengembangkan kreativitas siswa dalam implementasi kurikulum di kelas, misalnya model pembelajaran sinektik. Pada dasarnya, model pembelajaran sinektik dapat diterapkan pada semua kurikulum di sekolah, baik secara perseorangan maupun kelompok. Oleh karena itu, model ini sangat memungkinkan diimplementasikan terhadap kurikulum pendidikan IPS di Madrasah Ibtidaiyah. Bagaimanapun juga mutu implementasi kurikulum merupakan faktor determinan dalam meningkatkan mutu hasil belajar siswa.

Model pembelajaran sinektik dirancang untuk memperkuat struktur kognitif siswa. Berarti, teori yang mendasari model tersebut adalah teori kognitif. Teori ini kemudian dijadikan sebagai acuan untuk mempelajari model perlakuan yang efektif dalam rangka pengembangan kreativitas siswa di sekolah. Secara umum teori-teori kognitif melandaskan pandangannya pada aspek kreativitas sebagai fungsi dinamik dan interaktif dari perkembangan kognitif individu (Hersch, 1973). Pandangan ini menunjukkan bahwa kreativitas bukan hanya semata-mata akibat, tetapi juga dapat mengembangkan fungsi-fungsi kognitif yang lain. Teori kognitif sebagian besar memusatkan perhatiannya kepada kemampuan berpikir dan memecahkan masalah secara kreatif (Guilford, 1968; Torrance, 1974). Dengan demikian, model pembelajaran sinektik bertujuan untuk mengembangkan kreativitas siswa melalui aktivitas metaporik, "through the 
metaphoric activity of the synectics model, creativity becomes a conscious process" (Gordon dalam Joyce dan Weil (1992: 220). Dengan pelbagai metaporik tersebut diharapkan siswa dapat menghubungkan antar aspek, membandingkan antar obyek/gagasan yang sama dan/atau berbeda dengan menggunakan obyek pengganti (Gordon dalam Joyce dan Weil, 1992: 236). Sinektik juga merupakan strategi pembelajaran yang mempertemukan secara bersama unsur-unsur yang berbeda dan seolah-olah (secara fisik) tidak relevan untuk dipertemukan sehingga dapat diperoleh satu pandangan baru (Starko, 1995: 221). Proses ini dapat ditempuh dengan analogi langsung dan/atau analogi personal. Proses seperti ini diharapkan mampu mendorong siswa agar terlibat aktif dalam tindakan kreatif tatkala sebuah kurikulum/pembelajaran diimplementasikan di kelas. Demikian halnya dengan pembelajaran IPS, ia pun pada dasarnya bertujuan mengembangkan kreativitas/kemampuan berpikir kreatif siswa. Oleh karena itu, pelaksanaan model pembelajaran sinektik, yang bertujuan meningkatkan kemampuan berpikir kreatif siswa di MI pada mata pelajaran IPS ini, perlu dicoba dan diuji tingkat keefektifannya.

Fokus penelitian ini adalah mencari dan mengujicoba model pembelajaran sinektik dalam pembelajaran IPS di Madrasah Ibtidaiyah yang dapat meningkatkan kemampuan berpikir kreatif siswa. Secara khusus, penelitian ini dibatasi pada pengembangan model pembelajaran sinektik yang akan dipakai untuk mengembangkan kemampuan berpikir kreatif siswa dalam implementasi kurikulum IPS di Madrasah Ibtidaiyah. Tujuannya untuk menghasilkan suatu produk, yakni model pembelajaran sinektik yang diadopsi dari Gordon, yang dirancang untuk memperkuat struktur kognitif siswa sebagai acuan untuk mempelajari model perlakuan yang efektif dalam rangka meningkatkan kemampuan berpikir kreatif siswa Madrasah Ibtidaiyah. Model sinektik Gordon sedemikian rupa dimodifikasi dan disesuaikan dengan kondisi yang ada serta diselaraskan dengan kebutuhan pembelajaran Ilmu Pengetahuan Sosial, sehingga diperoleh model pembelajaran sinektik baru.

Tingkat keefektivan pengembangan model pembelajaran dikaji berdasarkan: (a) tolok ukur kemampuan model pembelajaran tersebut dalam mengembangkan kemampuan berpikir kreatif siswa yang didasarkan pada pemikiran teori kognitif tentang pengembangan struktur kognitif siswa, (b) model pendekatan kurikulum yang digunakan, dan (c) prosedur pembelajaran yang terdapat dalam model pembelajaran sinektik yang dikembangkan dalam penelitian ini.

Penelitian ini menggunakan pendekatan metode penelitian dan pengembangan. Borg dan Gall (1983: 772) mengatakan "educational research and development $(\mathrm{R} \& \mathrm{D})$ is a process used to develop and validate educational production". Dengan pengertian tersebut, maka serangkaian langkah penelitian dan pengembangan dilakukan secara siklus, artinya setiap langkah yang akan dilalui atau dilakukan selalu mengacu pada hasil langkah sebelumnya hingga pada akhirnya diperoleh suatu produk pendidikan yang baru. Menurut Borg dan Gall 
(1983: 775) ada 10 langkah atau tahap yang harus ditempuh dalam pendekatan ini. Dari 10 langkah tersebut dimodifikasi dengan cara menggabungkan atau mengintegrasikan tahap-tahap yang memiliki keterkaitan sehingga dapat disederhanakan menjadi lima langkah utama, yaitu: studi pendahuluan, perencanaan, uji coba, validasi dan pelaporan.

Subyek penelitian ini adalah guru dan siswa kelas V MI di wilayah Kabupaten Jombang Jawa Timur. Pada saat survei awal melibatkan 10 Madrasah Ibtidaiyah. Dalam survei berikutnya kemudian ditentukan dua Madrasah Ibtidaiyah yaitu; MI Mu'awwanah Janti dan MI Perguruan Mu'allimat Cukir sebagai lokasi uji coba terbatas. Dalam uji coba yang lebih luas ditambah tiga MI lagi yaitu MI Mujahidin, Islamiyah Al Wathaniyah dan Darul Faizin Catak Gayam. Pada tahap validasi, subyek penelitiannya sama dengan subyek penelitian pada survei awal. Dari 10 MI kemudian dibagi menjadi dua kelompok, yaitu MI kelompok eksperimen (yang pernah menjadi tempat uji coba model dan ada yang berstatus baik, sedang dan kurang) dan MI kelompok kontrol (yang tidak dijadikan tempat uji coba model juga ada yang berstatus baik, sedang dan kurang. Teknik analisis data yang digunakan adalah teknik statistik "sebaran frekuensi", analisis kualitatif dan analisis kuantitatif. Teknik statistik "sebaran frekuensi" dipakai untuk menganalisis hasil survei awal. Teknik analisis kualitatif dipakai untuk menganalisis hasil pengamatan kelas terhadap uji coba model pembelajaran sinektik (baik uji coba terbatas maupun uji coba lebih luas). Teknik analisis kuantitatif digunakan untuk mengetahui uji perbedaan. Proses analisa data menggunakan kaidah dan rumusan statistik melalui uji t dan uji Analisis of Variance (ANOVA).

\section{PEMBAHASAN}

Desain model pembelajaran sinektik merupakan model yang didasarkan pada asumsi psikologi kreativitas, yakni; a) memunculkan proses kreatif menuju kesadaran dan mengembangkan secara nyata kapasitas kreatif individu dan kelompok; b) kreativitas merupakan pola pengembangan mental yang baru. Banyak pemecahan masalah yang bersifat rasional dan emosional akan membangkitkan ide-ide segar, dan; c) elemen-elemen emosional dan irasional harus dipahami guna meningkatkan kesuksesan. Gordon menambahkan bahwa ada empat pandangan tentang model kreativitas; 1) kreativitas seseorang merupakan kegiatan sehari-hari, berlangsung seumur hidup dan dikembangkan dalam rangka meningkatkan kemampuan memecahkan masalah, mengekspresikan diri secara kreatif, memupuk rasa empati dan menjalin hubungan sosial; 2) proses kreatif bukan misteri, tetapi dapat diuraikan dan dimanfaatkan untuk melatih individu guna meningkatkan kualitas kehidupan mereka; 3) kreativitas hadir, tercipta dan berhubungan dengan semua bidang; dan 4) peningkatan berpikir kreatif baik secara individu maupun kelompok dapat dilakukan baik melalui ide maupun produk dalam berbagai hal (Gordon dalam Joyce dan Weil, 1986: 166-167). 
Penerapan model pembelajaran kreativitas/sinektis pada suatu kurikulum atau mata pelajaran bertujuan meningkatkan kemampuan berpikir kreatif siswa tentang mata pelajaran tersebut, "synectics is designed to increase the creativity of both individuals and group" (Joyce dan Weil, 1992: 254). Ada lima tahapan model pembelajaran sinektik yang dapat dijadikan acuan oleh guru dan siswa saat melaksanakan kegiatan belajar mengajar di kelas, yaitu;

1. Tahap in put substantif atau klarifikasi, yakni mengomunikasikan topik atau materi baru. Tahap ini sangat menunjang pada keberhasilan siswa terutama saat ia memperoleh materi baru. Di MI, tahap klarifikasi topik/materi baru ini ditandai dengan munculnya; (a) proses yang mempermudah siswa dalam memahami materi baru yang disampaikan oleh guru; (b) sejumlah kesulitan mengklarifikasi materi baru dan diselesaikan dengan menggunakan perumpamaan, kiasan dan contoh-contoh; (c) penerapan teknik tanya jawab kepada siswa terhadap materi baru yang dijelaskan oleh guru dan siswa tampak antusias menjawab pertanyaan guru. Antusiasnya siswa menjawab pertanyaan guru merupakan petunjuk ke arah sikap dan persepsi yang positif. Untuk mengetahui bahwa siswa telah belajar dengan baik, komponen guru dan kurikulum harus betul-betul saling berinteraksi dengan siswa (Knirk \& Gustafson, 1986: 18). Sebagai pelaksana kurikulum, guru dituntut untuk dapat memutuskan cara mengorganisasikan pelaksanaan kurikulum seoperasional mungkin. Sukmadinata (1988: 218) mengemukakan bahwa implementasi kurikulum itu hampir seluruhnya bergantung pada kreativitas, kecakapan, kesungguhan dan ketekunan guru. Berarti pada tahap ini, guru dituntut dapat menggambarkan struktur materi kurikulum. Tahap ini pun menuntut guru mengembangkan topik atau materi baru terutama saat menyusun rencana pembelajaran agar lebih terstruktur namun kreatif. Tanner \& Tanner (1980: 636-639) mengatakan bahwa guru profesional adalah guru yang creativegenerative yakni guru yang memikirkan hal yang akan dikerjakan dan selalu mencoba menemukan cara yang lebih efektif saat bekerja. Marsh \& Stafford (1988: 102) menegaskan bahwa guru sebagai pengembang kurikulum harus mampu mengidentifikasi masalah dan kebutuhan sekaligus mengatasi masalah dan kebutuhan kelasnya dengan merancang pembelajaran yang terstruktur dan tepat guna.

2. Tahap penggabungan dari proses analogi langsung, perbandingan analogi dan penjelasan perbedaan. Tahap ini diawali dengan meminta siswa mengajukan atau menganalogi secara langsung materi yang sedang dibahas melalui media bagan. Kegiatan ini memfasilitasi siswa dalam mentransmisi dan mentransformasi materi yang sedang dibahas. Di sini, guru bertugas membimbing dan mendorong para siswa agar memiliki keberanian untuk mengemukakan gagasan atau pendapat. Kegiatan membandingkan analogianalogi bertujuan mengidentifikasi dan menjelaskan kesamaan, perbedaan dan hubungan di antara aspek-aspek yang ada dalam objek atau kegiatan yang sedang berlangsung. Guru sedemikian rupa harus memotivasi siswa agar 
kemampuan siswa dalam memahami perbedaan-perbedaan yang ada dalam objek atau kegiatan yang dianalogikan dengan materi yang sedang dibahas terungkap dalam diskusi dan kemampuan berpikir kreatif siswa semakin meningkat. Penggunaan media pembelajaran berupa peta dan bagan ditujukan untuk memperkuat pemahaman siswa terhadap materi yang bersifat abstrak dan menyajikan materi secara visual dan terstruktur. Kemampuan membaca peta dan bagan tentang suatu materi mencerminkan kemampuan kognitif tingkat tinggi yang dapat meningkatkan kemampuan berpikir kreatif siswa. Di MI kemampuan tersebut dicirikan dengan; (a) siswa tampak fokus dan konsentrasi dalam mengikuti proses pembelajaran. Hal ini akan lebih terungkap saat guru meminta siswa mendeskripsikan analogi tersebut dan memberikan kesempatan kepada siswa mengajukan pertanyaan yang berhubungan dengan materi yang dibahas; (b) muncul pertanyaan-pertanyaan dari siswa yang memperlihatkan jenis pertanyaan berpikir. Pertanyaanpertanyaan yang diajukan siswa tersebut dapat mengindikasikan bahwa mereka melakukan proses belajar dengan benar. Saat pertanyaan-pertanyaan yang diajukan oleh guru dapat dijawab dengan baik oleh siswa maka akan diketahui bahwa materi yang dibahas oleh guru dapat dipahami oleh siswa.

3. Tahap analogi personal. Pada tahap ini, siswa diminta mengajukan pengandaian diri misalnya menjadi suatu objek, sesuai dengan materi yang dibahas. Hal yang dipikirkan, dirasakan dan diperbuat siswa tidak boleh terlalu dibatasi. Berikan kesempatan kepada mereka untuk berekspresi, mengemukakan gagasan dan pendapatnya seleluasa mungkin. Di MI kegiatan ini ditandai dengan gejala; (a) siswa tampak memunculkan gagasan-gagasan yang beragam, dengan menggunakan teknik curah pendapat (brainstorming). Hal ini menunjukkan bahwa model pembelajaran sinektik mampu melatih siswa untuk mengeluarkan gagasan-gagasan yang dimilikinya; (b) teknik curah pendapat yang digunakan dalam proses pembelajaran dapat meningkatkan kemampuan berpikir kreatif siswa.

4. Tahap eksplorasi. Dalam tahap ini guru meminta siswa untuk menjelajahi kembali atau menjelaskan kembali topik atau materi yang dibahas sebelumnya dengan menggunakan bahasa sendiri. Untuk itu, diperlukan bimbingan dari guru agar tahap ini berjalan dengan baik. Siswa juga diminta membuat catatan untuk mendokumentasikan hasil pekerjaannya. Di MI kegiatan ini ditandai dengan; (a) siswa dengan antusias menjelaskan kembali materi yang sebelumnya disampaikan oleh guru dengan menggunakan bahasa sendiri. Kata-kata yang digunakan siswa untuk menjelaskan kembali materi yang sudah disampaikan oleh guru, ternyata cenderung mengarah kepada makna yang sama. Artinya siswa sudah mampu mengolah materi pelajaran yang sebelumnya disampaikan oleh guru; (b) hasil pekerjaan siswa didiskusikan dengan teman-temannya, sehingga dapat dikaji secara bersama-sama.

5. Tahap kelima adalah memunculkan analogi baru. Tahap ini merupakan pengajuan analogi langsung atas materi yang sedang dibahas. Siswa 
diharapkan dapat mengajukan analogi langsung yang telah dikuasainya dan mampu menjelaskan persamaan dan perbedaannya. Untuk mencapai hal tersebut, guru perlu melakukan serangkaian kegiatan, yaitu meminta siswa mengajukan analogi langsung atas materi semula dengan objek atau kegiatan lain, mendiskusikan persamaan dan perbedaannya, menyimpulkan dan merangkum hasil pekerjaannya. Di sini, yang dipentingkan adalah argumentasi, mengapa sebuah objek atau kegiatan tertentu dianalogikan dengan materi yang sedang dibahas. Setelah selesai melaksanakan tahap ini, guru melakukan evaluasi terhadap hasil pekerjaan siswa yang mengandung unsur-unsur kemampuan berpikir kreatif. Tujuan dari kegiatan ini adalah untuk mengetahui kemampuan berpikir kreatif siswa (kelancaran, kelenturan, keaslian dan kerincian). Model pembelajaran sinektik di MI cenderung berkontribusi lebih baik kepada siswa dalam meningkatkan kemampuan berpikir kreatifnya.

\section{Model Pembelajaran Sinektik pada Mata Pelajaran IPS di MI}

Pembelajaran IPS dapat meningkatkan kemampuan berpikir siswa dan menanamkan nilai-nilai tertentu kepadanya (Al Muchtar, 2000: 37), termasuk keterampilan berpikir kreatif menjadi lebih baik. Kemampuan berpikir kreatif tersebut dapat mendasari dan menyiapkan anak memasuki kehidupan di masyarakat kelak setelah dewasa.

Kajian atas kehidupan sosial yang serba cepat berubah merupakan tindakan edukasi yang strategis bagi siswa sebab dengan memberi lebih banyak kesempatan kepada siswa untuk mencari solusi alternatif terhadap persoalanpersoalan yang serba tidak menentu merupakan bagian dari berpikir kreatif. Savage dan Amstrong (1996: 244-245) mengatakan "creative thinking helps us to change". Model pembelajaran sinektik dipandang relevan untuk mencapai tujuan mata pelajaran tersebut karena model ini bertujuan menjadikan pembelajaran IPS menjadi proses penanaman kreativitas secara sadar kepada siswa (Joyce dan Weil, 1992: 219). Pemberian kesempatan berlatih kepada siswa untuk mengajukan analogi dan/atau metaporik atas suatu persoalan sosial menjadikan wawasan dan pengetahuan siswa tentang materi IPS semakin luas dan mendalam.

Dalam posisinya sebagai pengembang kurikulum, guru dituntut mampu mengorganisasikan kurikulum secara operasional di kelas. Hunter (1971: 148), mengatakan bahwa guru profesional berhubungan dengan tiga keputusan, yaitu: a) penyeleksian tujuan dan materi pembelajaran, b) penetapan perilaku siswa yang diharapkan, dan c) penetapan rancangan (metodologi) yang digunakan guru untuk membantu siswa belajar dan mencapai hasil yang maksimal. Implementasi model pembelajaran yang merupakan bentuk nyata dari desain model pembelajaran sangat ditentukan oleh kemampuan dan kecakapan guru ketika mewujudkannya di kelas. Inilah maksudnya bahwa guru bukan hanya berperan sebagai pelaksana kurikulum, akan tetapi juga berperan sebagai pengembang kurikulum bagi kelasnya masing-masing. Dalam hubungannya dengan 
implementasi model pembelajaran sinektik, sesungguhnya guru memiliki posisi sentral bagi kelangsungan dan keberhasilan implementasi pada setiap tahap pembelajaran sejak tahap pertama hingga tahap terakhir. Guru dituntut mampu melaksanakan tugas-tugas yang dipersyaratkan pada setiap tahap pembelajaran, yang berbeda menurut jenis dan kualitasnya. Dengan demikian, tanpa adanya kompetensi dan komitmen dari guru maka implementasi model pembelajaran sinektik dimungkinkan tidak akan berlangsung dengan baik dan berhasil secara optimal.

Aspek lain yang perlu diperhatikan guru dalam pembelajaran adalah aspek siswa. Dalam implementasi kurikulum siswa ditempatkan sebagai subjek yang melakukan kegiatan belajar ditandai dengan adanya respons terhadap stimuli yang diberikan oleh guru. Belajar dipengaruhi oleh motivasi yang terdapat dalam diri siswa. Sukmadinata (1988) mengajukan tiga cara untuk membangkitkan motivasi siswa, yaitu: a) memilih bahan pembelajaran secara berarti, b) menciptakan kegiatan belajar yang dapat membangkitkan siswa untuk menemukan, c) menerjemahkan bahan ajar agar sesuai dengan tingkat perkembangan siswa. Kurikulum itu sendiri berisi pengetahuan yang terpilih dan dibutuhkan baik bagi pengembangan pengetahuan itu sendiri maupun bagi siswa dan lingkungannya (Sukmadinata, 1988: 127). Dalam hal ini isi kurikulum menggambarkan keterampilan dan kemampuan yang dapat dicapai siswa melalui proses belajar yang didasarkan pada materi. Pengorganisasian materi ini memperhatikan lingkup dan urutan kajian yang memiliki substansi dan proses tertentu.

1. Posisi Guru MI dalam Model Pembelajaran Sinektik

Dalam tahap pengembangan rencana pembelajaran guru mengorganisasi isi kurikulum agar dapat dioperasionalkan. Dalam posisinya sebagai pengembang kurikulum di kelas, guru harus mampu menetapkan topik baru dari materi/substansi yang akan diajarkan dan dikuasai oleh siswa. Untuk memudahkan siswa menangkap dan memahami materi baru, guru mengajukan analogi dan atau metaporik (yang merupakan aspek utama dalam model pembelajaran sinektik) dengan menggunakan perumpamaan atau kiasan dan contoh-contoh yang relevan dengan materi yang akan diajarkan.

Dalam kegiatan belajar mengajar, tahap-tahap pembelajaran yang terdapat dalam model pembelajaran sinektik mencerminkan proses pembelajaran. Berlandaskan tahapan tersebut, guru dapat menyelesaikan materi secara tepat waktu dan dapat mengontrol kegiatan atau proses belajar yang dilakukan oleh siswa. Temuan hasil penelitian memperlihatkan bahwa melalui implementasi model pembelajaran sinektik terjadi perbaikan kinerja guru dan model pembelajaran ini relatif lebih mudah diadopsi oleh guru sebab dengan adanya persamaan bentuk pembelajaran yakni dengan menggunakan teknik ekspositori menyebabkan guru tidak merasa asing dengan cara berceramah yang digunakan dalam kerangka model pembelajaran sinektik. 
Berdasarkan uji coba, pada tahap pengembangan rencana pembelajaran, guru masih perlu diberi pengarahan terutama dalam hal mengklarifikasi topik atau materi baru. Saat didiseminasikan model ini perlu disosialisasikan agar lebih terarah terutama pada bagian pengembangan rencana pembelajaran. Namun demikian model pembelajaran sinektik cukup efektif untuk memperbaiki aktivitas pembelajaran IPS di MI. Dalam posisi guru sebagai pengembang kurikulum di kelas, model ini efektif untuk memperbaiki kinerjanya yang mengarah kepada guru profesional.

2. Posisi Siswa dalam Implementasi Model Pembelajaran Sinektik

Salah satu komponen yang memiliki kontribusi terhadap kualitas pembelajaran adalah siswa. Proses pembelajaran akan berjalan baik ketika siswa merespons semua stimuli yang diberikan oleh guru. Model pembelajaran sinektik sebagai produk hasil penelitian ini berpeluang memperbaiki hasil pembelajaran siswa dan menumbuhkan komitmen siswa untuk belajar. Sukmadinata (1988: 146) menegaskan bahwa proses pembelajaran harus dikondisikan untuk membangkitkan dorongan pada diri siswa untuk menemukan sesuatu yang pada akhirnya dapat meningkatkan kemampuan berpikir kreatifnya. Model pembelajaran sinektik merupakan salah satu bentuk teknik pengembangan kreativitas seseorang yang bersifat mengait atau melekat dalam proses belajar mengajar. Dengan memberi kesempatan kepada siswa untuk mengajukan analogi dan atau metaporik, dimungkinkan siswa akan memiliki wawasan atau gagasan. Dengan demikian semakin banyak gagasan yang muncul diasumsikan kemampuan kreativitas siswa semakin berkembang. Evens dan Vernon (dalam Suharnan, 1998: 54) mengatakan bahwa kreativitas terjadi melalui asosiasi baik langsung maupun perantara, akan semakin banyak pula gagasan yang dimiliki, yang berarti makin kreatif orang tersebut. Berdasarkan temuan hasil penelitian menjelaskan bahwa kemampuan berpikir kreatif siswa menunjukkan adanya kemajuan. Artinya, terdapat perbedaan skor rata-rata kemampuan berpikir kreatif siswa antara sebelum mengikuti kegiatan pembelajaran yang menggunakan model pembelajaran sinektik dengan setelah mengikuti kegiatan pembelajaran yang menggunakan model pembelajaran sinektik. Dengan demikian dapat disimpulkan bahwa model pembelajaran sinektik pada mata pelajaran IPS dapat meningkatkan kemampuan berpikir kreatif siswa.

3. Posisi Materi dalam Implementasi Model Pembelajaran Sinektik

Relevansi model pembelajaran sinektik dengan mata pelajaran IPS telah dibahas pada kajian sebelumnya, dan pada bagian ini penjelasan lebih ditekankan pada cara meramu materi IPS bagi siswa yang berada dalam jenjang pendidikan dasar, khususnya kelas V MI. IPS merupakan salah satu mata pelajaran yang diajarkan di Madarasah Ibtidaiyah mulai dari kelas 3, yang mempelajari kehidupan sosial yang bahan kajiannya bersumber dari geografi, ekonomi, sejarah, sosiologi, antropologi, dan tata negara. IPS yang terbentuk dari ilmuilmu sosial tersebut terdiri dari berbagai fakta, konsep, dan generalisasi yang 
terintegrasi terkait dengan kehidupan sosial. Kehidupan sosial secara garis besarnya terdiri dari lingkungan fisik, sosial, dan budaya yang merupakan fokus pembelajaran IPS. Martorella (1994) menyatakan bahwa pengetahuan dalam pembelajaran IPS diwujudkan dalam bentuk fakta, generalisasi, keterampilan, hipotesis, kepercayaan, sikap, nilai, dan teori yang dikonstruksi dalam program IPS.

Killer (dalam Hamalik, 1992: 6) menyatakan IPS adalah studi yang memberikan pemahaman atau pengertian-pengertian tentang cara-cara manusia hidup, tentang kebutuhan-kebutuhan dasar manusia, tentang kegiatan-kegiatan dalam usaha memenuhi kebutuhan itu, dan tentang lembaga-lembaga yang dikembangkan sehubungan dengan hal-hal tersebut. Martorella (1994: 7) mengemukakan bahwa IPS adalah informasi yang terseleksi dan cara penyelidikan dari ilmu-ilmu sosial, informasi yang terseleksi dari bidang yang terkait secara langsung terhadap pemahaman individu, kelompok, dan masyarakat serta aplikasi informasi yang terseleksi dalam pendidikan kewarganegaraan. Jarolimek (1982: 4) mengungkapkan bahwa misi pokok IPS adalah membantu anak belajar mengenai dunia sosial di mana mereka hidup dan bagaimana kehidupan tersebut, belajar mengenai kenyataan-kenyataan sosial serta mengembangkan pengetahuan, sikap, dan keterampilan-keterampilan yang diperlukan untuk membantu mewujudkan kemanusiaan yang penuh dengan kecerahan dan kemajuan. Kajian materi IPS yang berfokus pada kegiatan dan kehidupan masyarakat dalam pengembangan pembelajarannya memiliki tujuan yang jelas untuk dicapai.

IPS sebagai salah satu mata pelajaran yang diajarkan mulai dari kelas 3 SD/MI memiliki beberapa sifat. Sumaatmadja (1984) mengemukakan bahwa sifat-sifat IPS: (1) merupakan pengetahuan praktis yang mempelajari, menelaah, dan mengkaji gejala dan masalah sosial sesuai dengan jenjang pendidikan dan perkembangan siswa, (2) multi dimensional yaitu meninjau suatu gejala atau masalah sosial dari berbagai dimensi kehidupan. Jadi dapat disimpulkan bahwa materi IPS mempelajari kenyataan dalam kehidupan sehari-hari di masyarakat yang dapat ditinjau dari beberapa aspek dalam kehidupan masyarakat.

Model pembelajaran sinektik melalui tahap-tahap pembelajarannya menyampaikan materi IPS dengan memberikan kesempatan siswa untuk bertanya, dan pendekatan ekspositori (naratif) memberikan kesempatan kepada siswa untuk mengembangkan rasa ingin tahu dan imajinasi mereka dalam berpikir. Dukungan dalam proses pembelajaran berupa penggunaan media belajar baik media peta maupun media bagan akan memperluas wawasan dan pengetahuan siswa pada materi IPS. Hal inilah yang oleh Schubert (1986) maupun Klein (1989) dijelaskan sebagai materi dalam arti substansi dan materi dalam arti proses. Kedua aspek tersebut merupakan tuntutan yang terdapat dalam kurikulum, sehingga penting untuk dipikirkan lebih lanjut mensosialisasikan model pembelajaran sinektik ini pada jenjang pendidikan dasar 
untuk mata pelajaran IPS sebagai salah satu alternatif model pembelajaran yang dapat memperbaiki kualitas pembelajaran.

Analisis yang dilakukan terhadap implementasi model pembelajaran sinektik dalam mata pelajaran IPS MI menghasilkan kesimpulan bahwa model pembelajaran sinektik layak untuk dipertimbangkan sebagai alternatif untuk memperbaiki kondisi pendidikan di Indonesia khususnya pendidikan dasar dalam kajian IPS. Di satu sisi model pembelajaran ini relatif mudah diadopsi oleh guru, dan di sisi lain hasil penelitian membuktikan bahwa model pembelajaran sinektik cukup efektif untuk memperbaiki kualitas pembelajaran dan mampu meningkatkan kemampuan berpikir kreatif siswa.

\section{Implementasi}

Hasil prasurvei memberi gambaran bahwa guru kurang memahami perlunya pengembangan desain/rencana pembelajaran, guru kurang memahami cara pengembangan rencana pembelajaran, dan dalam kegiatan belajar mengajar proses pembelajaran terkesan dilakukan seadanya. Temuan prasurvey ini mengindikasikan perlunya dilakukan pembenahan sejak tahap pengembangan perencanaan pembelajaran sampai kepada tahap pelaksanaan kegiatan pembelajaran termasuk di dalamnya pemilihan dan penetapan media pembelajaran. Dengan demikian modifikasi yang dilakukan dalam penelitian pengembangan adalah menambahkan prosedur pengembangan rencana pembelajaran yang didalamnya terdapat langkah pengembangan media pembelajaran (media peta/globe dan media bagan). Dari hasil penelitian terbukti bahwa pengembangan media pembelajaran ini sangat bermanfaat untuk mengendalikan tahap-tahap pembelajaran selanjutnya.

Implementasi model pembelajaran sinektik dalam mata pelajaran Ilmu Pengetahuan Sosial di Madrasah Ibtidaiyah menghasilkan kesimpulan bahwa model pembelajaran sinektik layak untuk dipertimbangkan sebagai alternatif untuk memperbaiki kondisi pendidikan di Indonesia khususnya pendidikan dasar dalam kajian IPS. Di satu sisi model pembelajaran ini relatif mudah diadopsi oleh guru, dan di sisi lain hasil penelitian membuktikan bahwa model pembelajaran sinektik cukup efektif untuk memperbaiki kualitas pembelajaran dan mampu meningkatkan kemampuan berpikir kreatif siswa.

Secara umum temuan hasil penelitian memberi gambaran kecenderungan peningkatan skor kemampuan berpikir kreatif siswa, sedangkan temuan hasil penelitian uji validasi memperlihatkan skor kemampuan berpikir kreatif siswa yang lebih tinggi dan secara signifikan berbeda jika dibandingkan skor kemampuan berpikir kreatif siswa yang diperoleh melalui pembelajaran secara konvensional. Uji validasi yang dilakukan pada lima madrasah dengan kualifikasi yang berbeda (baik, sedang, dan kurang) memperlihatkan kecenderungan yang sama yakni tingginya perolehan skor post test yang secara signifikan berbeda bila dibandingkan dengan skor pretest maupun skor posttest dari kelompok dengan pembelajaran konvensional. Atas dasar kedua temuan tersebut dapat 
disimpulkan bahwa pembelajaran yang dilakukan dengan menggunakan model sinektik efektif untuk meningkatkan kemampuan berpikir kreatif siswa.

Pengembangan media pembelajaran baik media peta/globe maupun media bagan dalam pengembangan rencana pembelajaran sebelum memasuki tahaptahap proses pembelajaran merupakan langkah awal perbaikan kinerja guru. Pengembangan media peta/globe dan media bagan memberi implikasi tuntutan terhadap guru untuk memahami substansi materi dan mampu mengidentifikasi konsep-konsep yang terdapat dalam materi pembelajaran. Temuan hasil penelitian menunjukkan pengembangan media peta/globe dan media bagan ini memberi efek munculnya rasa percaya diri guru sehingga memasuki tahap-tahap pembelajaran sebagai proses implementasi, guru tidak lagi mengalami kesulitan.

Tahap-tahap dalam model pembelajaran sinektik yang terstruktur secara sederhana menyebabkan guru lebih mudah mengelola proses pembelajaran. Hal ini tampak dari temuan hasil penelitian yang memperlihatkan guru dapat menyelesaikan materi pembelajaran tepat waktu dan dapat mengontrol proses belajar yang dilakukan oleh siswa. Atas dasar pengamatan bahwa kemampuan memahami dan mengembangkan media peta/globe dan media bagan serta kemampuan mengelola proses pembelajaran yang ternyata menghasilkan kemampuan berpikir kreatif siswa yang lebih baik, maka dapat disimpulkan bahwa model pembelajaran sinektik cukup efektif untuk memperbaiki kinerja guru.

Guru sebagai pihak pengguna yang bertanggung jawab atas terlaksananya kurikulum dalam bentuk kegiatan belajar mengajar menyadari bahwa implementasi kurikulum, khususnya kurikulum IPS di Madrasah Ibtidaiyah, masih belum optimal. Agar kualitas pembelajaran dapat diperbaiki, produk pengembangan ini dapat menjadi salah satu alternatif untuk mengoptimalkan proses pembelajaran, khususnya pembelajaran IPS. Model pembelajaran ini cukup mudah untuk diimplementasikan dan diadopsi oleh guru karena pada dasarnya model pembelajaran ini menggunakan analogi-analogi dan pendekatan ekspositori, yang sebenarnya guru telah terbiasa menggunakannya ketika menjelaskan materi pembelajaran, sehingga guru tidak terlalu asing terhadap penggunaan model pembelajaran ini. Model pembelajaran ini tidak membutuhkan sarana/fasilitas yang relatif kompleks, hanya perlu mengembangkan media pembelajaran berupa media bagan. Kebutuhan akan media peta dapat diatasi dengan menggunakan media peta geografis yang telah dimiliki oleh sekolah. Model pembelajaran ini telah teruji mampu meningkatkan kemampuan berpikir kreatif. Model pembelajaran produk pengembangan ini juga efektif memperbaiki kinerja guru yang apabila diimplementasikan membawa sejumlah konsekuensi, diantaranya kemauan guru untuk mengembangkan rencana pembelajaran yang dapat dipakai dan dalam hal ini terkandung tuntutan untuk memahami IPS sebagai disiplin ilmu dan menemukan sejumlah konsepkonsep yang dikembangkan dalam bentuk media bagan, konsistensi guru untuk melaksanakan pembelajaran sesuai dengan tahap-tahap pembelajaran, dan 
kemampuan guru untuk mengembangkan alat evaluasi hasil pekerjaan siswa yang mengacu pada peningkatan kemampuan berpikir kreatif siswa.

\section{SIMPULAN}

Model pembelajaran sinektik yang dikembangkan melalui penelitian ini pada dasarnya merupakan pengembangan dan modifikasi dari model sinektik yang dikemukakan oleh Gordon. Model pembelajaran hasil pengembangan tidak mengubah bentuk dasar model yang terdiri dari tujuh tahap utama, yakni: input substantif, analogi langsung, analogi personal, membandingkan analogi, menjelaskan berbagai perbedaan, eksplorasi, dan memunculkan analogi baru. Meskipun demikian dilakukan pengembangan dan modifikasi yang didasarkan pada kondisi dan kemampuan siswa di lingkungan Madrasah Ibtidaiyah setempat yakni menjadi 1)tahap input substantif berfungsi untuk mengkomunikasikan topik atau materi baru yang akan disampaikan oleh guru. Untuk itu dilakukan klarifikasi topik utama yang terdapat dalam materi pembelajaran. Mengacu pada kondisi kemampuan guru dan keterbatasan tingkat kemampuan siswa, maka dalam tahap ini guru dituntut untuk dapat memberikan gambaran struktur materi kurikulum. Model pembelajaran sinektik yang dikembangkan dalam penelitian ini memberikan tempat kepada guru dalam bentuk pengembangan topik atau materi baru pada waktu pengembangan rencana pembelajaran. Pada diri guru pun dibangun pola berpikir yang terstruktur. 2) tahap penggabungan dari tahap analogi langsung, perbandingan analogi, dan menjelaskan perbedaan. Pada tahap ini guru mengajukan atau membuat analogi langsung atas materi yang sedang dibahas melalui media bagan. Membandingkan terhadap analogi-analogi memiliki tujuan untuk mengidentifikasi dan menjelaskan kesamaan atau kaitan antara aspek-aspek yang ada dalam objek atau kegiatan yang dipakai sebagai analogi langsung. Sedangkan kegiatan menjelaskan perbedaan bertujuan untuk mengembangkan kemampuan siswa dalam memperoleh kejelasan tentang perbedaan-perbedaan yang ada dalam objek atau kegiatan yang dianalogikan dengan materi yang sedang dibahas. Mengacu pada kondisi kemampuan guru dan keterbatasan tingkat abstraksi siswa, maka tahap ini dilakukan pengembangan berupa bagan yang dikembangkan guru ketika mengembangkan rencana pembelajaran, dan memberikan perumpamaan/kiasan atau contohcontoh yang relevan dengan materi yang diajarkan guru dan sifatnya analogis untuk membantu siswa memahami materi yang bersifat abstrak. 3) Tahap analogi personal berfungsi sebagai langkah proses pengandaian diri seumpama ia (siswa) sebagai sesuatu objek atau kegiatan sesuai materi yang sedang dibahas. Apa yang dipikirkan, apa yang dirasakan, dan apa yang diperbuat seandainya sebagai suatu objek atau kegiatan tertentu merupakan hal-hal yang esensial dalam tahap ini. 4) Tahap eksplorasi berfungsi untuk menjelaskan kembali topik atau materi yang baru saja dibahas dengan menggunakan bahasanya siswa sendiri. Dalam tahap ini, guru memberikan bimbingan dan dorongan kepada siswa dan siswa membuat dokumentasi dari setiap hasil pekerjaannya. 5) Tahap memunculkan 
analogi baru berfungsi sebagai analogi langsung atas materi semula dengan objek atau kegiatan lain, mendiskusikan persamaan dan perbedaannya, menyimpulkan dan merangkum hasil pekerjaannya. Dalam langkah ini guru meminta siswa untuk memberikan argumentasi, mengapa sesuatu objek atau kegiatan tertentu dianalogikan dengan materi yang sedang dibahas, kemudian guru melakukan evaluasi terhadap hasil pekerjaan siswa. 6) Evaluasi hasil pekerjaan siswa dikembangkan berdasarkan atas tujuan pembelajaran yang hendak dicapai yaitu ingin mengetahui tingkat perkembangan kemampuan berpikir kreatif siswa (kelancaran, kelenturan, keaslian, dan keterincian).

\section{DAFTAR PUSTAKA}

Al Muchtar, S. 2000. Epistemologi Pendidikan Ilmu Pengetahuan Sosial. Bandung: Gelar Pustaka Mandiri.

Beauchamp, G.A. 1975. Curriculum Theory. Wilmette, Illinois: The Kagg Press.

Bennett, G. K., Sheasore, H. G., Wesman, A. G. 1982. Differential Aptitude Tests: Administrator's Handbook. New York: The Psychological Corporation.

Bloomberg, M. 1973. Creativity: Theory and Research. New haven, Conn: College and University Press.

Borg, W.R. \& Gall, M.D. 1983. Educational Research: An Introduction. New York: Longman.

Depdiknas. 2003. Kurikulum Pendidikan Dasar 2003: Landasan, Program, dan Pengembangan. Jakarta: Depdiknas.

Fullan, M. 1982. The Meaning of Educational Change. New York: Teacher College Press.

Gani, R. 1988. Pengajaran Sastra Indonesia Respons dan Analisis. Padang: IKIP Padang.

Gordon, J.J. William., \& Bruch, N. 1974. TET (Teacher Effectiveness Training). New York: David McKay Co, Inc

Gordon, J.J. William. 1980. Synectics Model. New York: Longman Publishers.

Guilford, J. P. 1968. Intelligence, Creativity and Their Educational Implication. San Diego, Calif: R. R. Knapp.

Hamalik, O. 1992. Studi Ilmu Pengetahuan Sosial. Bandung: Mandar Maju.

Hasan, S. H. 1993. “Tujuan Kurikulum Ilmu Pengetahuan Sosial”. Jurnal Pendidikan Ilmu Pengetahuan Sosial. Nomor Perdana 92-101.

Hersch, C. 1973. The Cognitive Functioning of the Creative Person. New haven, Conn: College and University Press.

Hunter, M. 1971. The Teaching Process. Dalam The Teacher's Handbook. Glenview-Illinois: Scot, Foresman \& Co.

Jarolimek, J. 1982. Social Studies in Elementary Education. New York: MacMillan Publishing Co. Inc.

Joyce, B. dan Weil, M. 1992. Models of Teaching. (Fourth Edition). Needham Heights Massachusetts: Allyn \& Bacon. 
Joyce, B. dan Weil, M. 2000. Models of Teaching. Boston: A Pearson education Company.

Klein, M. F. 1989. Curriculum Reform in the Elementary School. New York \& London: Teachers College Press.

Knirk, F.G. \& Gustafson, K.L. 1986. Instructional Technology, A Systematic Approach to Education. New York: Holt, Rinehart and Winston

Marsh, C. \& Stafford, K. 1988. Curriculum Practices. Sydney: Mc Graw-Hill Book Company.

Martorella, P.H. 1994. Social Studies for Elementary School Children: Developing Young Citizens. New York: MacMillan College Publishing Company.

Miller, J.P. dan Seller, W. 1985. Curriculum Perspective and Practice. New York: Longman.

Nur, A.M. 2008. Kreativitas Verbal. Online. Tersedia. http://www.nur.w0472nd.blogspot.com/2008/12/kreativitas-verbal.html 2 Januari 2009.

Pondok Bahasa. 2008. Penerapan Model Sinektik dalam Meningkatkan Kreativitas Menulis. Online. Tersedia:

http://pondokbahasa.wordpress.com/2008/12/15/penerapan-model-

sinektik- dalam-meningkatkan-kreativitas-menulis 15 Desember 2008.

Savage, V.T. dan Amstrong, G.D. 1996. Effective Teaching in Elementary Social Studies. (Third Edition). Englewood Cliffs, New Jersey: Prentice-Hall Inc.

Schubert, W. H. 1986. Curriculum Perspective, Paradigm, and Possibility. New York: MacMillan Publishing Company.

Soemantri, N. 2001. Menggagas Pembaharuan Pendidikan IPS. Bandung: PT. Remaja Rosdakarya.

Starko, J.A. 1995. Creativity in the Classroom: Schools of Curious Delight. New York: Longman Publishers.

Sukmadinata, N.S. 1988. Prinsip dan Landasan Pengembangan Kurikulum. Jakarta: P2LP'TK Ditjen Dikti Depdiknas.

Sumaatmadja, N. 1980. Manusia dalam Konteks Sosial Budaya dan Lingkungan Hidup. Bandung: Alfabeta.

Sumaatmadja, N. 1984. Metodologi Pengajaran IPS. Bandung: Alumni.

Syafruddin. 2001. Penerapan Model ATI dalam Pembelajaran IPS di SD. Disertasi Doktor pada SPS UPI Bandung: tidak diterbitkan.

Tanner, D., \& Tanner, L.N. 1980. Curriculum Development: Theory Into Practice. New York: MacMillan Publishing, Co. Inc. 